\title{
METABOLIC CHANGES IN BLOOD AND OVARIAN FOLLICULAR FLUID IN BALADI GOATS AS AFFECTED BY STORAGE TIME DURATION
}

\author{
A. A. Mohammed ${ }^{1}$ and A. Y. Kassab ${ }^{2}$ \\ 1- Department of Animal Production, Faculty of Agriculture, University of Assiut, 71526, Egypt, 2- \\ Department of Animal Production, Faculty of Agriculture, New Valley, University of Assiut, 71526, Egypt \\ Email:ayman15@yahoo.com
}

\section{SUMMARY}

The purposes of this study were to determine; 1) complete blood picture and serum metabolites after different times of storage (0, 4 and $8 \mathrm{~h})$ of either whole blood or blood serum; 2) metabolites concentration in follicular fluids harvested from different-sized follicles; 3) metabolites concentration in follicular fluids after different times of ovarian storage without $(0,4$ and $8 \mathrm{~h})$ or with $(0$ and $8 \mathrm{~h})$ holding medium in goats. Twenty four Baladi goats were slaughtered in this study. Blood samples were collected before immediate slaughter of goats. Fifteen pairs of ovaries with double dominance follicles were selected after slaughter and classified to three categories for collection of follicular fluids upon ovarian storage without $(0,4$ and $8 \mathrm{~h})$ or with $(0$ and $8 \mathrm{~h})$ holding medium. After immediate slaughter (Oh), follicular fluids were aspirated from two size classes of nonatretic follicles; subdominance $(\leq 3 \mathrm{~mm})$ and dominance $(>4 \mathrm{~mm})$. Moreover, follicular fluids were aspirated from dominance (>4mm) follicles upon ovarian storage without $(0,4$ and $8 \mathrm{~h})$ or with $(0$ and $8 \mathrm{~h})$ holding medium. Blood/serum and follicular fluid samples remained independent among goats and follicle size classes within goats. Blood serum and follicular fluid samples were assayed using photometric assays for complete blood picture and metabolites determination of glucose, total protein, albumin, triglycerides and total cholesterol. Results showed that blood cell picture, serum and follicular fluid metabolites (glucose, cholesterol and triglycerides) were changed over storage time of blood and ovaries. The extent of differences was time dependent. Thus, optimized storage time for ovaries containing large follicles is beneficial for embryo development in vitro which positively can affect the outcomes from embryo transferred to animals.

Keywords: Ovarian follicular fluid, blood metabolites, follicle size, storage, goats

\section{INTRODUCTION}

Biochemical changes of serum metabolites and ions over storage time and temperature were investigated (Monden et al., 2008). Because follicular fluid(FF) is partially transuded from blood, therefore, comparable changes of follicular fluid analytic due to ovarian storage are expected as in serum. Follicular fluid (FF) is also composed of locally produced substances inside the follicle resulting from the metabolic activities of cumulus and granulosa cells. Follicular fluid provides suitable microenvironment for the development, growth and maturation of the oocyte and play a vital role for the maintenance of fertility in the female (Kor and Moradi, 2013).

Compositional changes in follicular fluid may influence steroidogenesis, oocyte maturation and quality (Sato and Jiang, 2001). Previous in vitro studies have shown that follicular fluid metabolites may influence the capability of oocytes to mature and after fertilization to grow to the blastocyst stage (Arshad et al., 2005, Mohammed et al., 2005 and AbdEllah, 2010). Metabolites and ions concentration in the FF of the bovine ovary fluctuate considerably with the stage of estrous cycle, follicle size, follicle status and presence of large follicles (Atheya and Totey, 2002 and Mohammed et al., 2011). Leroy et al. (2004) indicated that the oocyte and the granulosa cells grow and mature in a changing biochemical environment from small to large follicles. In the previous studies, concentrations of FF metabolites such as glucose, cholesterol, triglycerides, total protein, albumin and globulin have been determined in camel (Mohammed and Mahmoud, 2011) and in ruminant (Mohammed, 2011). Our previous results demonstrated that the FF concentrations of biochemical metabolites changed from small to large follicles (Mohammed et al., 2011).

Developmental competence of the cumulusenclosed germinal oocytes to embryos and offspring was affected by age of animal (Martino et al., 1994), follicle size (Silva et al., 2002 and Mohammed, 2014) stage of estrous (BakiAcar et al., 2013) and ovarian storage (Luu et al., 2011). Therefore, ovarian storage over time from slaughtering may affect oocyte quality and/or follicular fluid composition.

In bovine, developmental competence of cumulus oocyte complexes to embryos in vitro was supreme when oocytes aspirated from ovaries 4 hours after slaughtering and decreased thereafter (Blondin et al., 1997). Such increase or decrease in developmental competence of oocytes is partially related to changes in conditions around the oocyte follicular fluid. Changes in blood serum analytes were studied through time of storage (Monden et al., 2008) whereas changes in follicular fluid metabolites were 
not tested yet. Sheep and goats production in the new valley governorate play important role in meat production. Therefore, metabolic changes in blood, serum and follicular fluid upon time of storage of blood and ovaries were tested in Baladi goats to optimize storage time of blood and ovaries containing large follicles.

\section{MATERIALS AND METHODS}

The slaughterhouse materials (ovaries and blood samples) of the present study were collected from slaughtered Baladi goats (in El-Dakhla country in the New Valley governorate) throughout May, 2013. New Valley governorates in Upper Egypt in western desert between $25^{\circ}$; $42 \& 30^{\circ} ; 47 \mathrm{E}$ longitude, $22^{\circ}$ $30 \& 29^{\circ} 30 \mathrm{~N}$ latitude and lies $77.8 \mathrm{~m}$ altitude above the sea level. The climate of this area is arid and dry, essentially that of the desert. Rainfall is almost negligible and the ambient temperature ranges from $46^{\circ} \mathrm{C}$ during summer days to $8{ }^{\circ} \mathrm{C}$ in the chilly winter nights. Blood samples were taken immediately before slaughter and ovaries were collected upon slaughter within five min. The collected samples (blood and ovaries) were transferred to the laboratory in container containing physiological saline solution having gentamicin sulphate within $10 \mathrm{~min}$. The recorded ambient temperature in the lab was between 33 and $35{ }^{\circ} \mathrm{C}$ and the relative humidity was between39.00 and $41.5 \%$.

\section{Experimental design}

Experimental design in this study is shown in Figure 1. Twenty four Baladi goats were selected and slaughtered in this study.

Blood sampling and analyses:

Blood samples $(10 \mathrm{ml})$ were obtained from the experimental goats (15 samples) just before slaughter using jugular vein puncture. Blood samples were decanted into two tubes, one tube with $0.14 \%$ anticoagulant (EDTA K3, Pty Ltd., Adelaide, SA, Astralia) for determination complete blood picture by (Sysmex xp-300 Japan) and the other one without anticoagulant for obtaining serum upon storage $(0,4$ and $8 \mathrm{~h}$ ). Blood samples after collection were kept in ice tank and immediately were taken to lab. Serum samples were obtained by centrifugation of blood samples for 15 min. at 5000 r.p.m. Upon centrifugation, blood serum was decanted into clean and dry Eppendorf tubes and exposed to glucose, total protein, albumin, triglycerides and cholesterol analysis using commercial kits. Globulin concentration was calculated by the difference between total protein and albumin concentrations. Analysis of blood serum metabolites were determined using photometer $5010 \mathrm{v} 5+$ in the laboratory of El-Dakhla hospital.

Selection of ovaries, distribution and storage:

Fifteen pairs of ovaries with comparable double dominance obtained from slaughtered goats were used in this study. Upon slaughtering, ovaries were transferred to the lab in container within ten min. Then, pairs of ovaries and blood were kept in ambient temperature ranged from 33 to $35^{\circ} \mathrm{C}$ and relative humidity from 39.00 to $41.50 \%$. Storage time for ovaries without holding medium and blood was 0 , 4 and 8 h or with holding medium ( 0 and 8$)$. Each pair of ovaries per animal with double dominance was distributed among the groups of the study (0, 4 and $8 \mathrm{~h}$ ). Holding medium is Ringer solution (Adwic, Egypt) supplemented with $0.2 \%$ glucose and $10 \%$ serum of the slaughtered goats.

\section{Follicular fluid aspiration and analysis}

Follicular fluid was aspirated separately from small $(\leq 3 \mathrm{~mm})$ and large follicles $(>4 \mathrm{~mm}$ diameter $)$ at $0 \mathrm{~h}$. At 4 and $8 \mathrm{~h}$ of storage, FF was aspirated only from large follicles $(>4 \mathrm{~mm}$ diameter). Follicular fluids were centrifuged at $5000 \mathrm{rpm}$ for $15 \mathrm{~min}$. Upon centrifugation, follicular fluid was decanted into clean and dry Eppendorf tubes and exposed to glucose, total protein, albumin, triglycerides and cholesterol analysis. The concentrations of such metabolites were measured calorimetrically using commercial kits. Analysis of this metabolites were determined using photometer $5010 \mathrm{v} 5+$ in the laboratory of El-Dakhla hospital.

\section{Statistical analysis}

Statistical analysis was carried out separately for each parameter $(\mathrm{T}) ; 1$ ) storage time of ovaries (i at 0 , 4 and $8 \mathrm{~h}$ ), 2) storage time of blood (i at 0, 4 and $8 \mathrm{~h}$ ) and 3) follicle size (i small and large). Data were analyzed using General Linear Model (GLM) procedure of SAS (1998) according to the following model.

$\mathrm{Yij}=\mu+\mathrm{Ti}+\mathrm{Eij}$

Where: $\mathrm{y}_{\mathrm{ij}}=$ The experimental observation $\mu=$ the mean,

$\mathrm{Ti}=$ The effect of parameters (storage time of ovaries, storage time of blood and follicle size)

Eij = Experimental error,

Duncan's multiple range test (1955) was used to compare the significant differences among means of the control and treated groups.

\section{RESULTS}

The current results indicated that storage times $(0$, 4 and $8 \mathrm{~h}$ ) and follicle sizes (subdominance \& dominance) of ovaries affect the values of complete blood picture and metabolites of serum and FF (Tables 1-5).

\section{A complete blood picture:}

A complete blood count (CBC) is a series of tests used to evaluate the composition and concentration of the cellular components of blood. Complete blood count was not affected over storage time of blood at 0, 4 and 8 h (Table 1). 


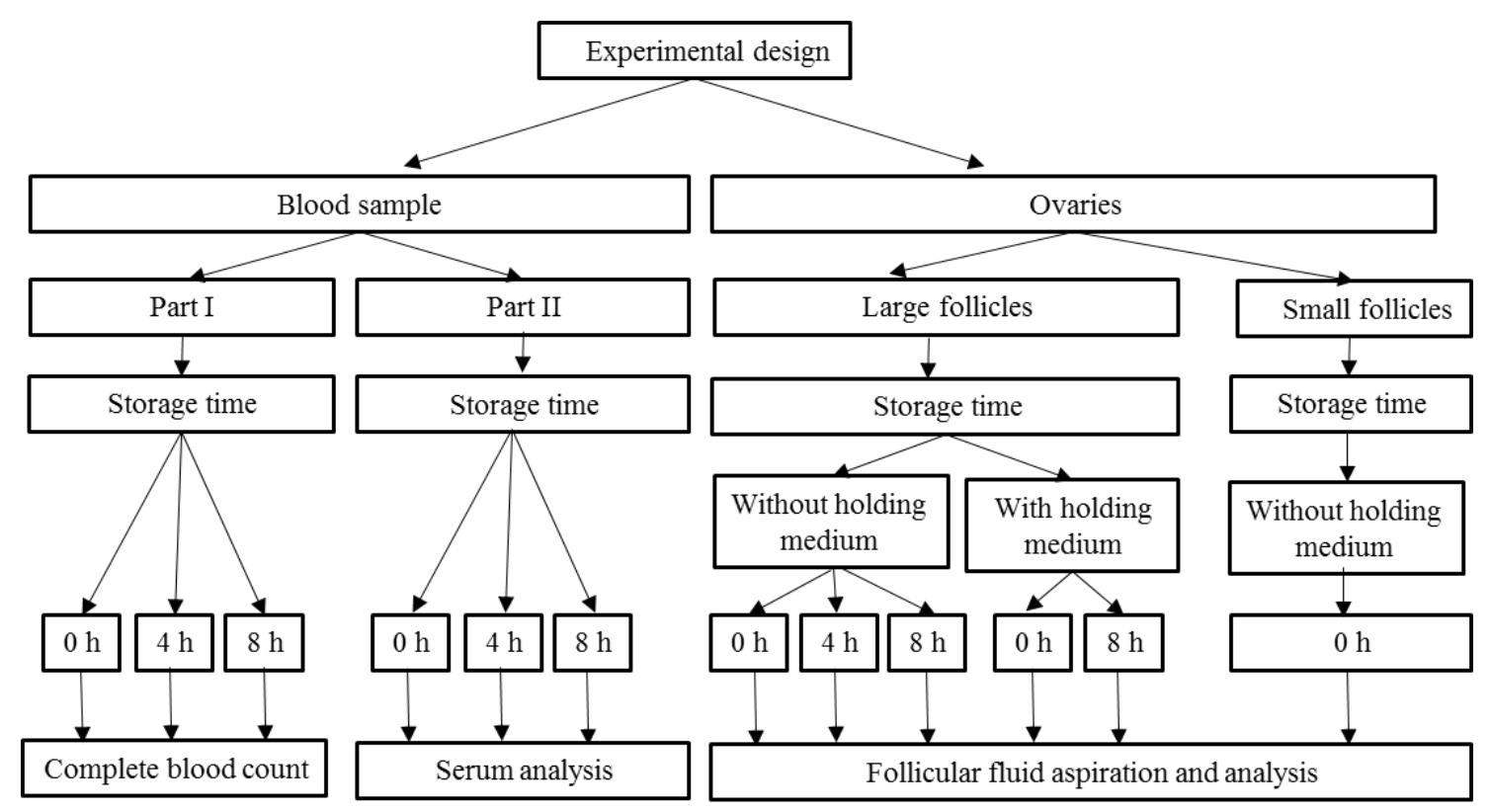

Figure 1: Schematic diagram of the experimental design

Table 1. Complete blood picture (Means \pm SE) upon storage time of slaughtered in Balidi goats

\begin{tabular}{|c|c|c|c|}
\hline \multirow{2}{*}{ Parameters } & \multicolumn{3}{|c|}{ Storage time } \\
\hline & $\mathbf{0 h}$ & $4 \mathrm{~h}$ & $8 \mathbf{h}$ \\
\hline Red blood cells, $106 / \mu 1$ & $6.01 \pm 0.97$ & $6.13 \pm 1.01$ & $6.21 \pm 0.96$ \\
\hline White blood cells, $103 / \mu 1$ & $16.26 \pm 0.23$ & $18.16 \pm 2.3$ & $17.06 \pm 1.29$ \\
\hline Hemoglobin g/dl & $8.2 \pm 0.5$ & $8.2 \pm 0.26$ & $8.16 \pm 0.28$ \\
\hline Hematocrit, \% & $22.3 \pm 2.1$ & $24.13 \pm 0.57$ & $23.3 \pm 1.5$ \\
\hline cell volume & $107 \pm 11.9$ & $112.96 \pm 2.43$ & $105.2 \pm 7.98$ \\
\hline cell volume, $\mathrm{MCH}, \mathrm{pg}$ & $39.3 \pm 2.02$ & $38.4 \pm 1.25$ & $36.83 \pm 1.06$ \\
\hline corpuscular hemoglobin concentration, g/dl & $37.13 \pm 5.55$ & $33.96 \pm 0.35$ & $35.23 \pm 3.63$ \\
\hline Lymphocyte, \% & $50.7 \pm 9.52$ & $54.06 \pm 8.21$ & $52.0 \pm 7.96$ \\
\hline Lymphocyte, $103 / \mu 1$ & $8.2 \pm 1.5$ & $9.83 \pm 2.02$ & $8.8 \pm 0.75$ \\
\hline Red blood cell distribution width & $16.83 \pm 2.6$ & $16.9 \pm 2.19$ & $17.36 \pm 2.45$ \\
\hline Platelet distribution width, $\%$ & $9.46 \pm 0.55$ & $9.53 \pm 0.66$ & $9.53 \pm 0.75$ \\
\hline platelet volume, $\mu \mathrm{m} 3$ & $13.4 \pm 0.52$ & $13.46 \pm 0.47$ & $13.63 \pm 0.57$ \\
\hline Platelet larger cell ratio & $50.53 \pm 8.83$ & $50.9 \pm 7.40$ & $52.7 \pm 9.1$ \\
\hline
\end{tabular}

Table 2. Metabolite concentrations of serum (Means \pm SE) of different storage time of blood in Baladi goats

\begin{tabular}{lccc}
\hline \multirow{2}{*}{ Metabolites } & \multicolumn{3}{c}{ Storage time } \\
\cline { 2 - 4 } & $94.6^{\mathrm{a}} \pm 11.34$ & $\mathbf{4} \mathbf{~ h}$ & $\mathbf{8 ~ h}$ \\
\hline Glucose $(\mathrm{mg} / \mathrm{dl})$ & $5.62 \pm 0.37$ & $75.0^{\mathrm{b}} \pm 10.86$ & $69.2^{\mathrm{b}} \pm 9.80$ \\
Total protein $(\mathrm{g} / \mathrm{dl})$ & $3.18 \pm 0.36$ & $5.82 \pm 0.52$ & $5.92 \pm 0.47$ \\
Albumin $(\mathrm{g} / \mathrm{dl})$ & $2.44 \pm 0.47$ & $3.42 \pm 0.37$ & $3.58 \pm 0.31$ \\
Globulin $(\mathrm{g} / \mathrm{dl})$ & $47.2 \pm 21.81$ & $2.40 \pm 0.27$ & $2.34 \pm 0.35$ \\
Triglycerides (mg/dl) & $69.0^{\mathrm{b}} \pm 9.5$ & $54.6 \pm 25.71$ & $58.4 \pm 25.54$ \\
Cholesterol (mg/dl) & $75.8^{\mathrm{ab}} \pm 4.14$ & $84.4^{\mathrm{a}} \pm 4.03$ \\
\hline
\end{tabular}

Values having different superscripts within the same row differ significantly $(\mathrm{P}<0.05)$

\section{Serum metabolites concentration upon different} storage time of blood:

In blood sample storage, serum glucose value showed a significant $(\mathrm{P}<0.05)$ decrease whereas, triglycerides and cholesterol values showed an increase $(\mathrm{P}>0.05)$ due to enzymatic cleavage of precursor molecules, while total protein, albumin and globulin values recorded not significant differences as a results of the variation of storage time (Table, 2).

Follicular fluid metabolites of different sized follicles:

Effect of follicle size $(\leq 3 \quad \&>4 \mathrm{~mm})$ on FF metabolites are presented in Table (3). The results indicated that glucose concentrations were 
significantly $(\mathrm{P}<0.05)$ high in $\mathrm{FF}$ of large sized follicles compared to those of small sized follicles. Total protein, albumin and globulin concentrations were unaffected as follicles became larger. In the present study, no-significant differences in triglycerides and cholesterol contents between small and large sized follicles were found.

Follicular fluid metabolites after 4 and 8 h of ovarian storage:

Ovarian storage affects follicular fluid total protein, albumin, globulin, triglycerides and cholesterol concentrations Table (4). Glucose concentration decreased $(\mathrm{P}<0.05)$, whereas cholesterol value increased $(\mathrm{P}<0.05)$ over time of storage.

\section{Follicular fluid metabolites after 0 and $8 \mathrm{~h}$ ovarian storage in holding medium:}

Follicular fluid metabolites after $8 \mathrm{~h}$ of ovarian storage in holding medium are shown in Table (5). The results indicated that holding medium led to insignificant changes in follicular fluid concentrations of triglycerides and cholesterol. While, glucose concentration was decreased $(\mathrm{P}<0.05)$ after $8 \mathrm{~h}$ of ovarian storage in a holding medium.

Table 3. Follicular fluid metabolites (Means \pm SE) of different sized follicles in Baladi goats

\begin{tabular}{lcc}
\hline \multirow{2}{*}{ Metabolites } & \multicolumn{2}{c}{ Sollicle size } \\
\cline { 2 - 3 } & Small & Large \\
\hline Glucose $(\mathrm{mg} / \mathrm{dl})$ & $41^{\mathrm{a}}{ }^{\circ} .80 \pm 9.03$ & $77 .{ }^{\mathrm{b}} \pm 6.63$ \\
Total protein $(\mathrm{g} / \mathrm{dl})$ & $4.84 \pm 0.24$ & $4.82 \pm 0.47$ \\
Albumin $(\mathrm{g} / \mathrm{dl})$ & $2.66 \pm 0.32$ & $2.78 \pm 0.33$ \\
Globulin $(\mathrm{g} / \mathrm{dl})$ & $2.30 \pm 0.61$ & $2.24 \pm 0.62$ \\
Triglycerides $(\mathrm{mg} / \mathrm{dl})$ & $41.4 \pm 6.22$ & $38.6 \pm 7.16$ \\
Cholesterol $(\mathrm{mg} / \mathrm{dl})$ & $42.2 \pm 8.58$ & $36.2 \pm 10.3$ \\
\hline
\end{tabular}

Values having different superscripts within the same row differ significantly $(\mathrm{P}<0.05)$

Table 4. Follicular fluid metabolites (Means \pm SE) after 4 and $8 \mathrm{~h}$ of ovarian storage in Baladi goats

\begin{tabular}{lccc}
\hline \multirow{2}{*}{ Metabolites } & \multicolumn{3}{c}{ Storage time $(\mathbf{h})$} \\
\cline { 2 - 4 } & $\mathbf{0}$ & $\mathbf{4}$ & $\mathbf{8}$ \\
\hline Glucose $(\mathrm{mg} / \mathrm{dl})$ & $77.0^{\mathbf{a}} \pm 6.63$ & $39.8^{\mathbf{b}} \pm 11.2$ & $15.0^{\mathbf{b}} \pm 1.58$ \\
Total protein $(\mathrm{g} / \mathrm{dl})$ & $4.82 \pm 0.47$ & $4.72 \pm 0.28$ & $4.80 \pm 0.43$ \\
Albumin $(\mathrm{g} / \mathrm{dl})$ & $2.78 \pm 0.33$ & $2.76 \pm 0.33$ & $2.80 \pm 0.34$ \\
Globulin $(\mathrm{g} / \mathrm{dl})$ & $2.24 \pm 0.62$ & $1.96 \pm 0.16$ & $2.02 \pm 0.25$ \\
Triglycerides $(\mathrm{mg} / \mathrm{dl})$ & $38.6 \pm 7.16$ & $37.8 \pm 4.43$ & $35.2 \pm 11.0$ \\
Cholesterol $(\mathrm{mg} / \mathrm{dl})$ & $36.2^{\mathrm{b}} \pm 10.3$ & $41.2^{\mathrm{b}} \pm 9.7$ & $55.0^{\mathrm{a}} \pm 7.9$ \\
\hline
\end{tabular}

Values having different superscripts within the same row differ significantly $(\mathrm{P}<0.05)$

Table 5. Follicular fluid metabolites (Means \pm SE) after 0 and $8 \mathrm{~h}$ of ovarian storage in a holding medium

\begin{tabular}{lcc}
\hline \multirow{2}{*}{ Metabolites } & \multicolumn{2}{c}{ Storage time (h) } \\
\cline { 2 - 3 } & $\mathbf{O ~ h}^{\mathbf{a}}$ & $\mathbf{8 ~ h}$ \\
\hline Glucose, $\mathrm{mg} / \mathrm{dl}$ & $79.2^{\mathbf{a}} \pm 2.77$ & $42.2^{\mathbf{b}} \pm 5.63$ \\
Total protein, g/dl & $4.96 \pm 0.51$ & $4.84 \pm 0.24$ \\
Albumin, g/dl & $2.88 \pm 0.30$ & $2.80 \pm 0.27$ \\
Globulin, g/dl & $2.28 \pm 0.61$ & $2.04 \pm 0.25$ \\
Triglycerides, mg/dl & $36.6 \pm 6.26$ & $35.6 \pm 4.72$ \\
Cholesterol, mg/dl & $37.8 \pm 7.04$ & $43.2 \pm 8.52$ \\
\hline
\end{tabular}

Values having different superscripts within the same row differ significantly $(\mathrm{P}<0.05)$

\section{DISCUSSION}

\section{A complete blood count:}

Data of a complete blood count (CBC) upon different times of storage of blood illustrated that values of red and white blood cells counts recorded in the present study were different from the values recorded by Elitok (2012). In the present study, the lower values of RBC's might be related to anemic status whereas higher values of WBC's might be related to immune response. The decrease values of red blood cells and hemoglobin concentrations in the present study may be due to the deficiency of copper in the land and also in the green fodder in the new valley governorate. This deficiency led to adverse effect on the counts of red blood cells and hemoglobin concentrations. Yousef (2006) and Mostafa et al. (2008) reported that copper deficiency in grazing sheep led to anemia and growth retardation as a result of decreasing red blood cells and hemoglobin concentrations in blood. In addition, higher values of WBC and lower of RBC in the present study may be due to unsuitable environmental condition (heat stress, nutrition deficiency, infection....etc) which caused anemic status. Generally, anemic status led to increase WBC specially as lymphocytes (Kaneko et al., 2008).Also, the results indicated that the values of $\mathrm{RBC}$ and WBC were increased with time ( 4 and $8 \mathrm{~h}$ ) of storage (Table 1). In addition, the slight increase of RBC's 
might be attributed to fragmentation of RBC's. This could be confirmed through variation of RBC's sizes.

\section{Serum metabolites concentrations upon different time of storage of blood:}

Serum metabolites concentrations upon time of storage of blood are presented in Table (2). Serum metabolites concentrations fluctuated upon time of storage of blood. It seems that prolonged contact of serum with red blood cells resulted in an exchange of substances between serum and the red blood cells, which can cause either increase or decrease of metabolites concentrations in the serum. In this study, glucose concentrations were significantly $(\mathrm{P}<0.05)$ decreased over time of storage. Monden et al. (2008) found that serum glucose decreased starting from three hours storage for blood samples stored at room temperature. The decrease of serum glucose concentration may be related to the sensitivity of glucose to temperature or distinguishing of glucose in higher temperature (Marjani, 2007).

In this study, total protein, albumin, globulin and triglycerides concentrations recorded not significantly differences as a result of variation time of blood storage. Triglycerides concentrations were consistent with those obtained in previous study (Donnelly et al., 1995). This apparent increase could be caused by cleavage of glycerol from phospholipids (Heins et al., 1995).

The present results indicated that serum cholesterol values were significantly $(\mathrm{P}<0.05)$ increased upon storage time of blood. Heins et al. (1995) reported that cholesterol value was stable for 7 days at $9^{\circ} \mathrm{C}$, but not at $23-27^{\circ} \mathrm{C}$. In other studies, storage of serum at room temperature produced adverse changes, i.e. an increase in the HDL- and a decrease in the LDL-cholesterol concentration (Bachorik et al., 1980 and Hankinson et al., 1989).

\section{Follicular fluid metabolites of different sized follicles:}

The present results indicated that glucose concentration was significantly $(\mathrm{P}<0.05)$ high in follicular fluid of large sized follicles compared to that of small sized follicles. Our result is in agreement with the other results of ruminant species (Thakur et al., 2003; Nandi et al., 2008; Tabatabaei and Mamoei, 2011; Mohammed, 2011 and Mohammed et al., 2011). Leroy et al. (2004) also observed that the concentration of glucose in the follicular fluid of small follicles was $21 \%$ lower than in large sized follicles which are consistent with this study. There is a possibility that glucose metabolism (per unit follicular fluid volume) is less intensive in the large follicles compared to the small ones, resulting in a lower consumption of glucose from follicular fluid.

Concentrations of total protein, albumin and globulin due to follicle size are presented in Table (2). Total protein concentration was unaffected as follicles became larger. This result is in consistent with other studies (Leroy et al., 2004; Arshad et al.,
2005 and Tabatabaei et al., 2011). They indicated that total protein concentration was relatively uniform throughout the follicular development. In contrast other studies reported that total protein concentration decreased as follicle become larger (Mohammed 2011 and Mohammed et al., 2011). This difference might be related to differences in time of storage and method of analysis.

Triglycerides and cholesterol contents from small to large sized follicles were decreased insignificantly in the present study (Table 3), which is consistent with other studies (Thakur et al., 2003; Mishra et al., 2003; Leroy et al., 2004; Thangavel and Nayeem, 2004; Arshad et al., 2005; Nandi et al., 2007; Tabatabaei and Mamoei, 2011 and Tabatabaei et al., 2011). Sharrna et al. (1996) found an increase in FF cholesterol values collected from follicles $2-3 \mathrm{~mm}$ in diameter and then declined steadily until the follicles reached ovulatory size in goats. Moreover, the triglycerides value decreased non- significantly from early antral follicles to ovulatory follicles. In this study, follicular fluid was aspirated from small $(\leq 3$ $\mathrm{mm}$ ) and large follicles (>4 mm). The decrease in cholesterol level in the large sized follicles might be attributed to the conversion of cholesterol to steroid hormones, estrogen and progesterone during steroidgenesis. The increase in triglyceride level in small sized follicles might be attributed to the use as alternate sources of energy for cumulus and granulosa cells in follicles (Harlow et al., 1987 and Leroy et al., 2004). Moreover, the other reason for the increase in triglycerides in the small follicles was that the triglycerides did not pass through the follicular membrane (Grummer and Carrol, 1988) and the follicular triglyceride levels were mainly a result of local metabolic processes (Leroy et al., 2004).

\section{Follicular fluid metabolites after 4 and $8 h$ of ovarian storage}

The changes in FF metabolites over time of storage might be related to metabolic activities of cumulus and granulosa cells in follicles (Table, 4). Sirard and Blondin (1996) has presented evidence in review showing that the developmental competence of bovine oocytes may be enhanced by exposure of ovaries to warm conditions for a few hours before recovering the oocytes. In previous study, Blondin et al. (1995), where the whole ovaries were stored at about $30^{\circ} \mathrm{C}$ for 3-4 h after slaughter, had reported significantly improved oocyte developmental competence. They suggested that the $4 \mathrm{~h}$ of storage after slaughter might be created a specific follicular microenvironment in which changes occurred in the oocyte similar to those normally associated with the pre-ovulatory follicle in the preceding hours leading up to ovulation. Time of storage after slaughter resulted in changes in FF metabolites which are expected to increase or decrease the developmental competence of oocytes. 
Follicular fluid metabolites after 0 and $8 \mathrm{~h}$ of ovarian storage in holding medium

Follicular fluid metabolites after 0 and $8 \mathrm{~h}$ of ovarian storage in holding medium are presented in Table (5). The results indicated that holding medium led to a slight change in follicular fluid concentrations of glucose, triglycerides and cholesterol. This might be attributed to presence of glucose, serum and ions in holding medium which kept glucose level and consequently triglycerides were not used as an energy source.

In earlier studies, follicular fluid or tissue-culture medium was used as holding medium for ovaries/oocytes. Schwartz et al. (1998) reported results indicating that satisfactory embryo production could be obtained after storing COC's in tissueculture medium 199 (TCM-199) or bovine follicular fluid at $20^{\circ} \mathrm{C}$ for up to $10 \mathrm{~h}$. Therefore, the changes in follicular fluid metabolites were kept, to a degree, to a favorable level for oocyte development.

\section{CONCLUSION}

From the present results it can be concluded that cell blood count, serum and follicular fluid metabolites (glucose, cholesterol and triglycerides) were changed over storage time of blood and ovaries. The extent of differences was time dependent. Thus, optimized storage time should be not more than $4 \mathrm{~h}$ for ovaries containing large follicles for embryo development in vitro which positively can affect the outcomes from embryos transferred to animals.

\section{REFERENCES}

AbdEllah, M.R., H.A. Hussein and D.R. Derar, 2010. Ovarian follicular fluid constituents in relation to stage of estrus cycle and size of the follicle in buffalo. Veterinary World, 3: 263-267

Arshad, H.M., N. Ahmad, Z.U. Rahman, H.A. Samad, N. Akhtarand and S. Ali, 2005. Studies on some biochemical constituents of ovarian follicular fluid and peripheral blood in buffaloes. Pakistan Veterinary Journal, 25(4): 189-193

Atheya, U.K. and S.M. Totey, 2002. Steroid concentration of the buffalo (Bubalus bubalis) ovarian follicular fluid. Buffalo Journal, 18(1): 137-141

Bachorik, P.S., R. Walker, K.D. Brownell, A.J. Stunkard and P.O. Kwiterovich, 1980. Determination of high density lipoproteincholesterol in stored human plasma. Journal Lipid Research, 21: 608-616

BakiAcar, D., M.K. Birdane, N. Dogan and H. Gurler, 2013. Effect of the stage of estrous cycle on follicular population, oocyte yield and quality, and biochemical composition of serum and follicular fluid in Anatolian water buffalo. Animal Reproduction Science, 137:(1-2) 8-14

Blondin, P., K. Coenen, L.A. Guilbault and M.A. Sirard, 1997. In vitro production of bovine embryos: Developmental competence is acquired before maturation. Theriogenology, 47: 10611075

Blondin, P., L.A. Guilbault and M.A. Sirard, 1995. In vitro production of bovine embryos: developmental competence is acquired before maturation. Theriogenology 43: 168

Donnelly, J. G., S. J. Soldin, D. A. Nealon and J.M. Hicks, 1995. Stability of twenty-five analyte in human serum at 22 degree ${ }^{\circ} \mathrm{C}, 4$ degrees ${ }^{\circ} \mathrm{C}$ and 20 degree ${ }^{\circ} \mathrm{C}$. Pediatr. Pathol. Lab. Led. 15(6): 869-874

Duncan, D. B., 1955. Multiple range and multiple Ftest. Biometrics, 11: 1-42

Elitok, B., 2012. Reference values for hematological and biochemical parameters in Saanen goats breeding in Afyonkarahisarprovince. Kocatepe Veterinary Journal, 5 (1): 7 - 11

Grummer, R.R. and D.J. Carroll, 1988. A review of lipoprotein cholesterol metabolism: importance to ovarian function. Journal of Animal Sciences, 66: $3160-3173$

Hankinson, S.E., S.J. London, C.G. Chute, R.L. Barbieri, L. Jones, L.A. Kaplan, F.M. Sacks and M.J. Stampfer, 1989. Effect of transport on the stability of biochemical markers in blood. Clinical Chemistry, 35: 2313-2316

Harlow, C.R., R. M. L. Winston, R. A. Margara and S.G. Hillier, 1987. Gonadotrophic control of human granulosa cell glycolysis. Human Reproduction, 2: 649-653

Heins, M., W. Heil and W. Withold, 1995.Storage of serum or whole blood samples? Effects of time and temperature on 22 serum analytes. European Journal of Clinical Chemistry and Clinical Biochemistry, 33: 231-238

Kaneko, J; W. Harvey. John and L. Bruss. Michael (2008). Clinical biochemistry of domestic animals. Elsevier Academic Press publications, $6^{\text {th }}$ Ed.U S A.

Kor, N.M. and K. K. Moradi, 2013. A review of biochemical metabolites concentration and hormonal composition of ovarian follicular fluid in domestic animals. Annual Review and Research in Biology, 3(3):246-255

Leroy, J.L.M.R., T. Vanholder, J.R. Delanghe, G. Opsomer, A. VanSoom, P. E. J. Bols and A. de Kruiff, 2004. Metabolite and ionic composition of FF from different-sized follicles and their relationship to serum concentrations in dairy cows. Animal Reproduction Sciences, 80:201211

Luu, V.V., Z. Namula, Y. Kaedei, F. Tanihara and T. Otoi, 2011. Effects of ovary storage time on the quality and meiotic competence of cat oocytes. Reproduction Fertility and Development, 24(1): 205-206

Marjani, A., 2007. Effect of storage time and temperature on some serum analytes. The Internet Journal Laboratory Medical, 2 (2): DOI: $10.5580 / 7$ ed 
Martino, A., M.J. Palomo, T. Mogas and M.T. Paramio, 1994. Influence of the collection technique of prepubertal goat oocytes on in-vitro maturation and fertilization. Theriogenology, 42: 859-873

Mishra, O.P., J.N. Pandey and P.G. Gawande, 2003. Study on biochemical constituents of caprine ovarian follicular fluid after superovulation. Asian Australian Focus, 16:1711-1715

Mohammed, A.A., 2011. Total protein, urea, glucose, triglycerides and cholesterol concentrations of ruminant follicular fluid in relation to follicle size and estrous stage. African Journal Animal Biomedical Sciences, 6: 127-132

Mohammed, A.A., 2014. Maturation and developmental competence of selectively enucleated germinal vesicle oocytes of mammals upon nuclear transfer. International Journal of Current Engineering and Technology, 4 (1): 292299

Mohammed, A.A. and G.B. Mahmoud, 2011. Some reproductive parameters of growing, adult nonpregnant and pregnant she- camel slaughtered in Assiut Governorate. Egyptian Journal Animal Production, 48: 75-84

Mohammed, A.A., G.A. Abd El-Hafiz and H.M. Ziyadah, 2011. Changes of follicular fluid composition in relation to dietary urea level and follicle size during follicular and luteal phases in Saidi Ewes. Theriogenology Insight, 1 (1): 31-42

Mohammed, A. A., J. Karasiewicz, K. Papis and J. A. Modlinski, 2005. Oocyte maturation in the presence of randomly pooled follicular fluid increases bovine blastocyst yield in vitro. Journal Animal Feed Sciences 14 (3): 501-512

Monden, S., M. Tanaka and H. Takahashi, 2008. Pretest blood samples at clinical laboratories: effects of temperature and duration of blood sample storage on measurements. Rinsho Byori, 56(3): 239-242

Mostafa, A. Salleh, M. Bassam Al- Salahy and Samera A. Sanousi, 2008. Corpuscular oxidative stress in desert sheep naturally deficient in copper. Small ruminant Research, 80: 33-38

Nandi, S., V. Girish Kumar, B.M. Manjunatha and P.S.P. Gupta, 2007. The biochemical composition of ovine follicular fluid in relation to follicle size. Developmental Growth Differentiation, 49: 61-66

Nandi, S., V. Girish Kumar, B.M. Manjunatha, H.S. Ramesh and P.S.P. Gupta, 2008. Follicular fluid concentrations of glucose, lactate and pyruvate in buffalo and sheep, and their effects on cultured oocytes, granulosa and cumulus cells. Theriogenology, 69: 186-196

SAS, 1998. SAS User's guide: Statistics. SAS Inst. Inc., Cary, NC, USA

Sato, E and J.Y. Jiang, 2001. Follicular development and ovulation in hypothyroid rdw rats. Molecular Cell Developmental Biology and Reproduction, 8: $249-256$

Schwartz, J., M.R. Schneider, J.L. Rodriques, and H.D. Reichenbach, 1998. Effect of short-term storage of bovine oocytes in different media and temperatures on the subsequent in vitro embryo development. Theriogenology, 49: 217

Sharrna, R.K., R. Vats and A.K. Sawhney, 1996. Changes in follicular lipids during follicular growth in the goat (Capra hircus) ovary. Small Ruminants Research, 20: 177-180

Silva, J.R.V., M.A.L. Ferreira, S.H.F. Costa, R.R. Santos, F.C.A. Carvalho, A.P.R. Rodrigues, C.M. Lucci, S.N. Ba Âo and J.R. Figueiredo, 2002. Degeneration rate of preantral follicles in the ovaries of goats. Small Ruminants Research, 43: 203-209

Sirard, M.A. and P. Blondin, 1996. Oocyte maturation and IVF in cattle. Animal Reproduction Science., 42: 417-426

Tabatabaei, S. and M. Mamoei, 2011. Biochemical composition of blood plasma and follicular fluid in relation to follicular size in buffalo. Comparative Clinical Pathology, 20: 441-445

Tabatabaei, S., M. Mamoei and A. Aghaei, 2011. Dynamics of ovarian follicular fluid in cattle. Comparative Clinical Pathology, 20: 591-595

Thakur, R.S., R.A.S. Chauhan and B.K. Singh, 2003. Studies on biochemical constituents of caprine follicular fluid. Indian Veterinary Journal, 80: 160-162

Thangavel, A. and M. Nayeem, 2004. Studies on certain biochemical profile of the buffalo follicular fluid. Indian Veterinary Journal, 81: 25-27

Yousef, E.M., 2006. Some minerals profile in sheep serum in New Valley governorate. Thesis. Faculty of Veterinary Medicine, Assiut University Assiut, Egypt. 
التغيرات في نواتج التمثيل للام والسائل الحويصلي للمبيض فى الماعز البلدي نتيجة تاثير فترة التخزين عبد الناصر أحمد محمد' و أيمن يوسف كساب'

1ـ قسم الإتتاج الحيو اني ، كلية الزراعة ، جامعة أسيوط ؟ـ قسم الإنتاج الحيو اني ، كلية الزراعة بالو ادى الجليد ، جامعة اسيوط،

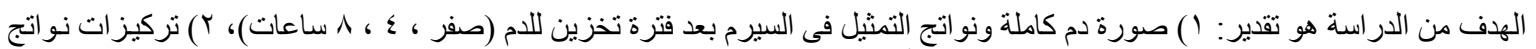

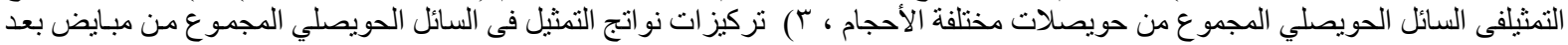

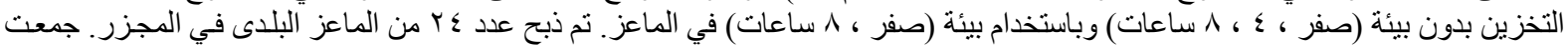

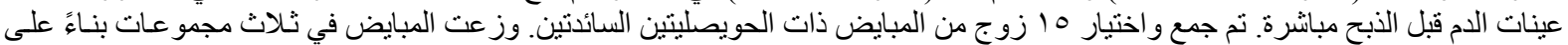

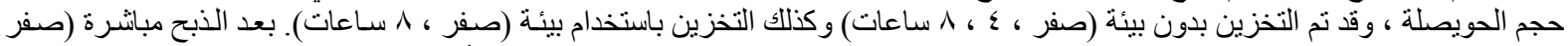

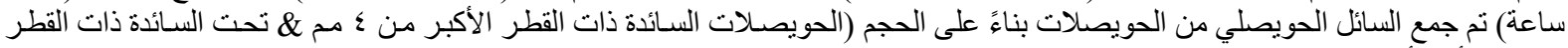

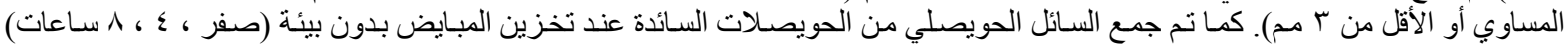

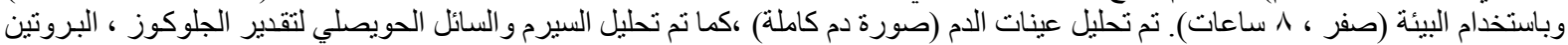

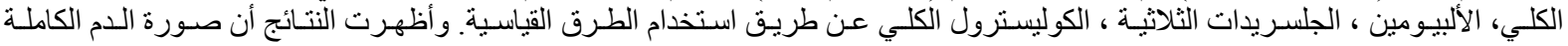

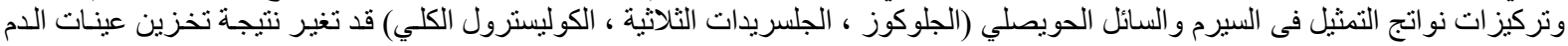

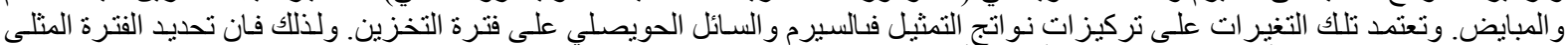

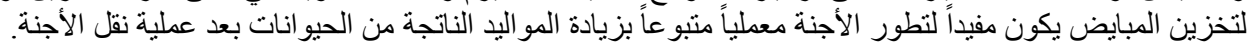

